
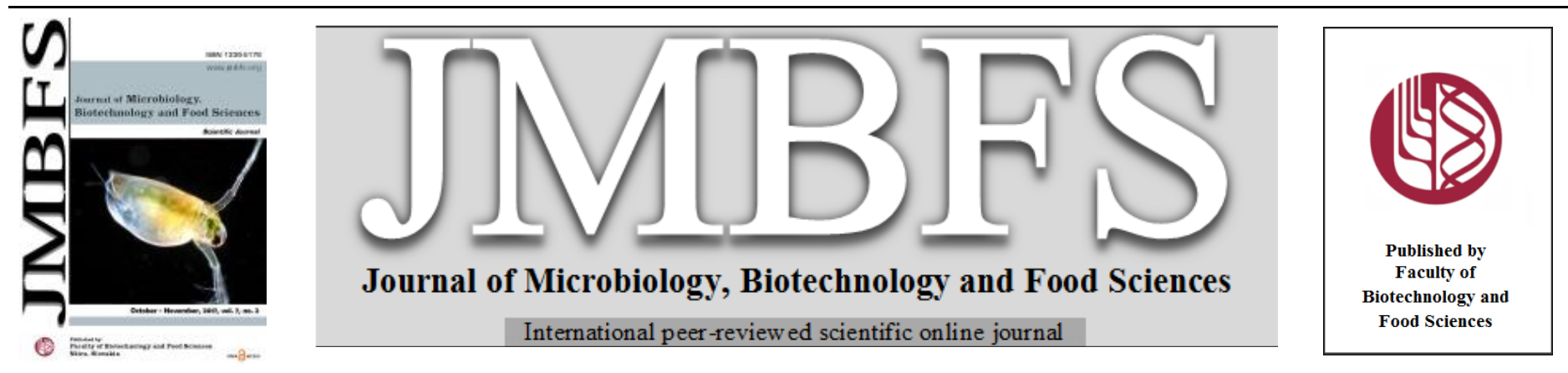

\title{
INACTIVATION OF ESCHERICHIA COLI O157:H7 ON GREEN BELL PEPPER BY CHLORINE DIOXIDE SIMULATING PACKINGHOUSES PROCESS
}

\author{
Osvaldo López-Cuevas ${ }^{1}$, José Andrés Medrano-Félix ${ }^{2}$, Nohelia Castro-del Campo ${ }^{l}$, Célida Martínez-Rodríguez ${ }^{1}$, and Cristóbal \\ Chaidez ${ }^{* 1}$
}

\begin{abstract}
Address(es):
${ }^{1}$ Laboratorio Nacional para la Investigación en Inocuidad Alimentaria. Centro de Investigación en Alimentación y Desarrollo A. C., Culiacán, MÉXICO. Carretera a Eldorado km. 5.5 campo El Diez, Culiacán, Sinaloa México P.C. 80110. Phone (52) 667 760-55-36, Fax (52) 667 760-55-37.

${ }^{2}$ CONACYT- Laboratorio Nacional para la Investigación en Inocuidad Alimentaria. Centro de Investigación en Alimentación y Desarrollo A. C., Culiacán, MÉXICO. Carretera a Eldorado km. 5.5 campo El Diez, Culiacán, Sinaloa México P.C. 80110. Phone (52) 667 760-55-36, Fax (52) 667 760-55-37.
\end{abstract}

*Corresponding author: chaqui@ciad.mx

doi: 10.15414/jmbfs.2017.7.2.149-152

ARTICLE INFO

Received 1. 11. 2016

Revised 22. 8. 2017

Accepted 12. 9. 2017

Published 1. 10. 2017

Regular article

OPEN $\partial_{\text {ACCESS }}$

\begin{abstract}
In this study, packinghouses spraying disinfection process was simulated to compare the effectiveness of aqueous chlorine dioxide and sodium hypochlorite in reducing Escherichia coli $\mathrm{O} 157: \mathrm{H} 7$ on bell pepper surface. Bell peppers inoculated with $7.74 \log _{10} \mathrm{CFU}$ of $E$. coli $\mathrm{O} 157: \mathrm{H} 7$ were placed in a rotary mixer $(60 \mathrm{rpm})$, and sprayed with chlorine dioxide and sodium hypochlorite. Chlorine dioxide at 5 mg L ${ }^{-1}$ during 20-30 s reduces from 7.74 $\log _{10} \mathrm{CFU}$ of E. coli $\mathrm{O} 157: \mathrm{H} 7$ adhered on bell pepper to undetectable numbers, while the exposition with chlorine dioxide at $\mathrm{pH} 6$ and 8 during $10 \mathrm{~s}$ was necessary to reduce 4.25 and $3.90 \log _{10} \mathrm{CFU}$, respectively. On the other hand, sodium hypochlorite at $200 \mathrm{mg} \mathrm{L}^{-1}$ at pH 6 reduced 2.89, 3.25 and $3.54 \log _{10} \mathrm{CFU} /$ bell pepper at 10,20 and $30 \mathrm{~s}$, respectively. Spraying disinfection process using aqueous chlorine dioxide was more effective than sodium hypochlorite applications, therefor chlorine dioxide is an effective alternative to reduce $E$. coli $\mathrm{O} 157: \mathrm{H} 7$ on bell pepper surface.
\end{abstract}

Keywords: Disinfection, Sanitizers, Spray washing, Vegetables, Food safety

\section{INTRODUCTION}

The increasing worldwide tendency of including fresh produce on the diet has also been related to the occurrence of foodborne illnesses due to consumption of contaminated produce. In the United States, every year occurs 9.4 million episodes of foodborne illnesses, 55,961 hospitalizations and 1,351 deaths; much of these cases, reported as outbreaks, have been related to the consumption of contaminated fruits and vegetables, (Scallan et al., 2011; CDC, 2006; CDC, 2008; CDC, 2013). Several studies using microbial source tracking indicate that cross-contamination offers to bacteria, parasites and virus a pathway to reach fruits and vegetables (Beuchat, 1996; Ravaliya et al., 2014; Harwood et al., 2014). Microbial contamination throughout the production chain may occur as a consequence of inadequate or scarce sanitation process during production chain, resulting in diverse punctual contamination sources, especially when Good Agricultural and Manufacturing Practices are not strictly followed (Cummings $\boldsymbol{e t}$ al., 2001; CDC, 2002; CDC, 2003; CDC, 2005; CDC, 2008).

Pathogenic bacteria, such as Escherichia coli $\mathrm{O} 157: \mathrm{H} 7$ has been responsible for at least 18 foodborne outbreaks in the last ten years in the United States, and nine of these were related to vegetables (CDC, 2016) causing economic losses up to $\$ 271$ million dollars per year (Hoffmann et al., 2015). In order to eliminate pathogens from fruits and vegetables surface, the Food and Drug Administration (FDA) published in the Code of the Federal Regulations (21CFR 173 315) a list of chemicals allowed for washing or assisting the peeling of fruits and vegetables (US FDA, 2008) in which chlorine-based disinfectants appear as an alternative for this application.

At present, sodium hypochlorite is the widest sanitizer used for washing fruits and vegetables in packinghouses. Several studies confirm the inactivation effect of chlorine. Beuchat et al. (1998) reduced the presence of E. coli O157:H7 on tomato surface in $2.08 \log _{10}$ colony forming units per $\mathrm{cm}^{2}\left(\mathrm{CFU} / \mathrm{cm}^{2}\right)$ by spraying with chlorinated water at $200 \mathrm{mg} \mathrm{L}^{-1}$ at $\mathrm{pH}$ 6.8. Chaidez et al. (2007) were able to reduce $3 \log _{10}$ CFU/tomato of Salmonella enterica serovar Typhimurium ( $S$. Typhimurium) under laboratory conditions when chlorinated water was sprayed (sodium hypochlorite) at $200 \mathrm{mg} \mathrm{L}^{-1}$ at $\mathrm{pH}$ 7. However, chlorine has some undesirable characteristics, since alkaline $\mathrm{pH}$ and organic matter reduce its effectiveness; in addition, toxic by-products are generated when reacting with organic matter (Beuchat, 1998). Therefore, chloramines, ultraviolet light, gamma rays, ozone, peracetic acid and chlorine dioxide have been evaluated as an alternative to disinfect water and fresh produce external areas (Rudd and Hopkinson, 1989; Banach et al., 2015).

Several studies about chlorine dioxide tested on fruits and vegetables surfaces reported reductions of pathogens from 4 to $7 \log _{10}$ CFU (Han et al., 2000a; Du et al., 2003). Also, Singh et al. (2002) showed reductions of $1.72 \log _{10}$ CFU/g of E. coli $\mathrm{O} 157: \mathrm{H} 7$ when applied chlorine dioxide at $20 \mathrm{mg} \mathrm{L}^{-1}$ for $15 \mathrm{~min}$ on lettuce surface. In another study by Pao et al. (2007) evaluated chlorine dioxide at $20 \mathrm{mg}$ $\mathrm{L}^{-1}$ on tomatoes surface by the immersion method, reaching reductions up to 5 $\log _{10} \mathrm{CFU} / \mathrm{cm}^{2}$ of Salmonella enterica and Erwinia carotovora. Recently, Pao et al. (2009) reduced Salmonella in $5 \log _{10} \mathrm{CFU} / \mathrm{cm}^{2}$ from tomato surface by immersing in $5 \mathrm{mg} \mathrm{L}^{-1}$ of aqueous chlorine dioxide for $10 \mathrm{~s}$, aided by rotating brushes. Even though aqueous chlorine dioxide is highly effective against pathogenic bacteria, its application in the fresh produce industry is scarce. We hypothesized that aqueous chlorine dioxide applied by spraying on green bell peppers has a better effect on microbial reduction than sodium hypochlorite Therefore, the objective of this research was to compare the spraying application of chlorine dioxide and sodium hypochlorite in reducing E. coli O157:H7 inoculated on bell pepper surface simulating packinghouses disinfection operation

\section{MATERIALS AND METHODS}

\section{Green bell peppers (Capsicum annuum L.)}

Large-size of green bell peppers (GBP) free of physical injuries, were directly collected from fields provided by a local grower. In order to avoid natural microbial presence, GBP were immersed in $300 \mathrm{mg} \mathrm{L}^{-1}$ of chlorine for $2 \mathrm{~min}$ as described by Chaidez et al. (2007). Subsequently they were immersed in sodium thiosulfate solution (1\%) for $1 \mathrm{~min}$. Finally, the bell peppers were rinsed with sterile distilled water and dried inside of a biosafety cabinet for $30 \mathrm{~min}$ at room temperature $\left(\sim 28^{\circ} \mathrm{C}\right)$, and then placed in sterile bags and stored at $10^{\circ} \mathrm{C}$ for $24 \mathrm{~h}$ prior to the experiment. 


\section{Inoculum preparation}

A strain of E. coli O157:H7 (CECT 4076) was used for the assays. Previous to the experiment, the strain was subjected to confirmation by multiplex PCR, amplifying the genes $h l y \mathrm{~A}$, eae $\mathrm{A}, f l i \mathrm{C}, s t x 1$ and $s t x 2$ as described by Wang $\boldsymbol{e t}$ al (2002). Once confirmed, E. coli O157:H7 was grown in Trypticase Soy Broth (BD Bioxon, Mexico) and incubated at $37^{\circ} \mathrm{C}$ for $24 \mathrm{~h}$ with constant agitation and centrifuged at $13,800 \times \mathrm{g}$ for $10 \mathrm{~min}$ at $4^{\circ} \mathrm{C}$. The supernatant was discarded and the cell pellet was washed twice to minimize non-cellular components associated with the solution and after diluting using phosphate buffered solution (PBS) 0.01 M. Appropriate dilutions were spread plate on mFC agar (DB Difco Laboratories USA) with rosolic acid [10 $\mathrm{mL}$ of a $1 \%$ solution in $0.2 \mathrm{~N} \mathrm{NaOH}$ per litter], and incubated at $37^{\circ} \mathrm{C}$ for $24 \mathrm{~h}$ yielding an inoculum of $9.3 \log _{10} \mathrm{CFU} / \mathrm{mL}$.

\section{Disinfectants preparation}

First, chlorine dioxide gas was generated with a Chlorine Dioxide Plant (Bello Zon $^{\circledR}$ type CDKc 170, Prominent ${ }^{\circledR}$ ) generator, using as precursors hydrochloric acid at $30 \%$ and sodium chlorite at $25 \%$ under the manufacturer specifications. Second, chlorine dioxide gas was dissolved in $20 \mathrm{~L}$ of sterile distilled water in an amber airtight container, and subsequently adjusted to 2 and $5 \mathrm{mg} \mathrm{L}^{-1}$; whereas for the preparation of chlorine solutions, sodium hypochlorite (Clorox ${ }^{\circledR} 5 \%$ ) was used and adjusted to $200 \mathrm{mg} \mathrm{L}^{-1}$ by diluting it in sterile distilled water. The concentrations of chlorine dioxide and sodium hypochlorite were determined by using DPD (N,N-diethyl-p-phenylenediamine), method 10126 and 8021, respectively, with a spectrophotometer 2010 DPD colorimetric method (DR2010, Hach Co. Ames, IA, USA) as described by APHA, (1998).

The $\mathrm{pH}$ solutions were adjusted with phosphoric acid to 6 and 8 (Pinnacle $530 \mathrm{pH}$ meter, Corning, USA). Phosphate buffered solution was used as a control treatment in order to determine the dragging spray effect in both disinfectants and $\mathrm{pH}$ levels. The solutions were prepared $1 \mathrm{~h}$ before use.

\section{Green bell peppers inoculation}

Disinfected GBP were placed in a sterile bag containing $50 \mathrm{~mL}$ of a $E$. col O157:H7 suspension (9.3 $\log _{10} \mathrm{CFU} / \mathrm{mL}$ ) and manually agitated for $1 \mathrm{~min}$, then let them dry in a biosafety cabinet for $1 \mathrm{~h}$ at $25^{\circ} \mathrm{C}$ and stored at $4{ }^{\circ} \mathrm{C}$ overnight to allow bacterial adherence to surface. In order to determine E. coli $\mathrm{O} 157: \mathrm{H} 7$ adhered concentration, the inoculated GBP were rubbed with a sterile sponge (Nasco Whirl-Pak ${ }^{\circledR}$ Speci-Sponge $18 \mathrm{oz}$ ) for $1 \mathrm{~min}$, then each sponge was placed in a bag containing $25 \mathrm{~mL}$ of sterile distilled water and vigorously massaged for 1 min. Subsequently, an aliquot of $1 \mathrm{~mL}$ was taken to perform the microbial enumeration as described in the inoculum preparation section (APHA, 2001) This procedure was repeated three times.

\section{Disinfectant's treatments evaluation}

Disinfection was carried out to simulate the passage of GBP through a washing conveyor belt in a packinghouse. Briefly, bell peppers were inoculated as described in the green bell peppers inoculation section. The bell peppers were placed in a rotary mixer spin (Rotamix RKVSD, ATR, MD, USA) at a speed of $60 \mathrm{rpm}$ and sprayed from a distance of $30 \mathrm{~cm}$, which is the distance that the sprinkler is placed in the conveyor belt at the packinghouses (Chaidez $\boldsymbol{e t}$ al., 2007). Each disinfectant solution was applied for 10,20 and $30 \mathrm{~s}$ at $25^{\circ} \mathrm{C}$ and the spent volumes sprayed were $19.5,38.3$ and $57.45 \mathrm{~mL}$, respectively (Table 1). In order to stop the disinfectant bactericidal activity and to quantify the bacterial concentration left on each GBP after treatment these were individually rubbed with a sponge containing sodium thiosulfate $(0.1 \%)$, which were then placed in a sterile bag. Later, a $1 \mathrm{~mL}$-aliquot was taken from the bag (as described in green bell peppers inoculation section) to perform the microbial enumeration as described in the inoculum preparation section (APHA, 2001). This procedure was done in triplicate.

Table 1 Treatments applied on bell pepper inoculated with E. coli O157:H7.

\begin{tabular}{|c|c|c|c|c|c|c|}
\hline Treatment & $\begin{array}{l}\text { Concentration } \\
\left(\mathrm{mg} \mathrm{L}^{-1}\right)\end{array}$ & & $\mathrm{pH}$ & \multicolumn{3}{|c|}{ Contact time (s)/Volume (mL) } \\
\hline & & \multirow{4}{*}{\multicolumn{2}{|c|}{6}} & \multirow{4}{*}{$10 / 19.5$} & \multirow{4}{*}{$20 / 38.3$} & \multirow{4}{*}{$30 / 57.45$} \\
\hline Chlorine dioxide & 2 & & & & & \\
\hline Chlorine dioxide & 5 & & & & & \\
\hline Sodium hypochlorite & 200 & & & & & \\
\hline
\end{tabular}

\section{Statistical Analysis}

A three-factor completely randomized design in triplicate was established. The analysis of variance (ANOVA) was performed using the MINITAB Software version 14.0. Comparisons between means were determined using Tukey test with a significance level of $\mathrm{p}<0.05$.

\section{RESULTS AND DISCUSSION}

\section{Disinfectant activity of sodium hypochlorite on GBP}

The use of sodium hypochlorite and chlorine dioxide for reduction of $E$. coli 0157:H7 from bell pepper surface, showed different and significant results according to disinfectant product $(\mathrm{p}=0.000), \mathrm{pH}(\mathrm{p}=0.013)$ and time of contact $(\mathrm{p}=0.000)$, furthermore, the interaction $\mathrm{pH}$-disinfectant showed significan differences, indicating that lowering $\mathrm{pH}$ values can negatively affect the bactericidal effect of both disinfectants [Table 2].

Table 2 Interaction $\mathrm{pH}$-disinfectant for the reduction of E. coli $\mathrm{O} 157: \mathrm{H} 7$

\begin{tabular}{lccc}
\hline Product & $\mathbf{p H}$ & Reduction $(\mathbf{L o g})$ & p Value \\
\hline \multirow{2}{*}{$\mathrm{NaClO}$} & 6 & 3.23 & 0.0000 \\
& 8 & 1.72 & \\
$\mathrm{ClO}_{2}$ & 6 & 6.58 & 0.0000 \\
\hline
\end{tabular}

The application of sodium hypochlorite at $200 \mathrm{mg} \mathrm{L}^{-1}$ and $\mathrm{pH} 6$ on inoculated bell peppers showed reductions of $2.89,3.25$ and $3.54 \log _{10}$ CFU/GBP at contact times of 10, 20 and $30 \mathrm{~s}$, respectively. However, at $\mathrm{pH} 8$ the bactericidal activity of sodium hypochlorite against $E$. coli $\mathrm{O} 157: \mathrm{H} 7$ was negatively affected, being necessary $30 \mathrm{~s}$ of contact time to achieve maximum reductions of $2.82 \log _{10}$ CFU/GBP (Figure 1), suggesting that $\mathrm{pH} 6$ favours better conditions to obtain free chlorine and disinfectant effect. Results for sodium hypochlorite at $\mathrm{pH} 6$ were similar to that obtained by Chaidez et al. (2007) whom achieved $3 \log _{10}$ CFU reduction of $S$. Typhimurium attached to tomato surfaces by spraying 200 $\mathrm{mg} \mathrm{L}^{-1}$ of sodium hypochlorite for $30 \mathrm{~s}$ at $\mathrm{pH}$ 7. In this work, a higher reduction was achieved probably because of the acidic $\mathrm{pH}$ of the solution, which exerted lethal activity of chlorine solutions given by the amount of hypochlorous acid $(\mathrm{HOCl})$ as free chlorine at $\mathrm{pH}$ closer to 6 (Beuchat, 1998).

In a similar study, Beuchat et al. (1998) inoculated E. coli $\mathrm{O} 157: \mathrm{H} 7$ on tomatoes disinfecting them by spraying 5 or 6 times with chlorinated water at 200 and
$2000 \mathrm{mg} \mathrm{L}^{-1}$ at $\mathrm{pH} 6.8$ letting chlorine to act for 1, 2, 3, 5 and $10 \mathrm{~min}$, achieving a maximum reduction level at $5 \mathrm{~min}\left(2.08\right.$ and $2.06 \log _{10} \mathrm{CFU} / \mathrm{cm}^{2}$ at 200 and $2000 \mathrm{mg} \mathrm{L}^{-1}$, respectively), showing that chlorine provides a limited reduction of no more than $3 \log _{10} \mathrm{CFU} / \mathrm{cm}^{2}$ of $E$. coli $\mathrm{O} 157: \mathrm{H} 7$. In this study, the reduction was higher than mentioned above despite that sodium hypochlorite was inactivated with sodium thiosulfate after disinfectant application, suggesting that $\mathrm{pH} 6$ and the prolonged spraying could help to reduce the pathogen, since the reduction achieved was 3.25 and $3.54 \log _{10} \mathrm{CFU} / \mathrm{GBP}$ at $\mathrm{pH} 6$ and contact time of 20 and $30 \mathrm{~s}$, respectively. This may be attributed to the measuring dimensions by $\mathrm{cm}^{2}$ by Beuchat et al. (1998) and measures by complete green bell pepper in our study.

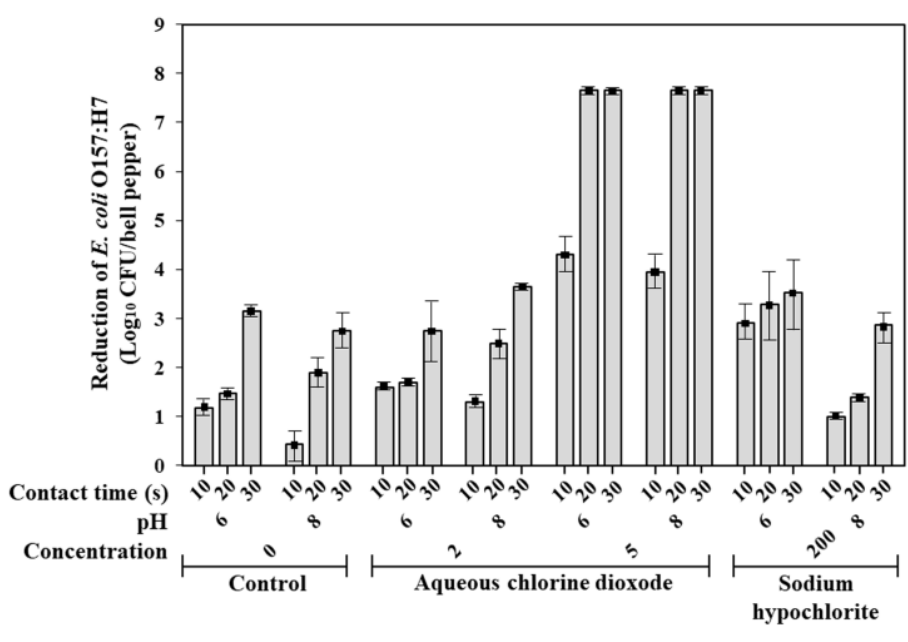

Figure 1 Effect of sodium chlorine and aqueous chlorine dioxide in reducing $E$. coli $\mathrm{O} 157: \mathrm{H} 7$ on green bell pepper. Control $=0$; Chlorine dioxide $=2 \mathrm{mg} \mathrm{L}^{-1}$ and $5 \mathrm{mg} \mathrm{L}^{-1}$; Chlorine $=200 \mathrm{mg} \mathrm{L}^{-1}$. Values are mean \pm standard error $(n=3)$. 


\section{Disinfectant activity of chlorine dioxide on GBP surface}

The use of chlorine dioxide resulted in the best option for microbial reduction on bell pepper surface. In this regard, the application of $5 \mathrm{mg} \mathrm{L}^{-1}$ chlorine dioxide achieved the major reductions of E. coli $\mathrm{O} 157: \mathrm{H} 7$, showing at $\mathrm{pH} 6$ and $\mathrm{pH} 8$, reductions of $7.74 \log _{10} \mathrm{CFU} / \mathrm{GBP}$ at contact times of 20 and $30 \mathrm{~s}$, respectively. Interestingly, the time of $10 \mathrm{~s}$ showed favourable reductions of 4.25 and 3.9 $\log _{10} \mathrm{CFU} / \mathrm{GBP}$ at $\mathrm{pH} 6$ and 8 , respectively. Sodium hypochlorite treatments at $30 \mathrm{~s}$ and $\mathrm{pH} 8$ reduced more than $2 \log _{10} \mathrm{CFU} / \mathrm{GBP}$, as well as chlorine dioxide at $2 \mathrm{mg} \mathrm{L}^{-1}$ at $\mathrm{pH} 8$ in $20 \mathrm{~s}$. Based on results, the main factor affecting $E$. coli $\mathrm{O} 157: \mathrm{H} 7$ viability was the contact time $(\mathrm{p}=0.000)$, because the longer spraying time the greater reduction of the microorganism obtained. In regard to acidity, $\mathrm{pH}$ 6 was more effective $(\mathrm{p}=0.0126)$ in reducing the microorganism, however this effect was only observed in sodium hypochlorite but not in chlorine dioxide and control buffer solutions. Results indicate that disinfectant concentration levels, contact time and $\mathrm{pH}$ influenced the effectiveness of both disinfectants. It was also observed that aqueous chlorine dioxide at $2 \mathrm{mg} \mathrm{L}^{-1}$ can reduce $E$. coli $\mathrm{O} 157: \mathrm{H}^{7}$ from GBP surface at $\mathrm{pH} 6$ in $30 \mathrm{~s}$ close to $3 \log _{10}$ CFU/GBP, while at $\mathrm{pH} 8$ and contact time of $20 \mathrm{~s}$ were achieved more than $2 \log _{10}$ CFU/GBP of reduction. The effectiveness of chlorine dioxide treatments was improved using $5 \mathrm{mg} \mathrm{L}^{-1}$, with noticeable effect by the $\mathrm{pH}$ of the solution.

Han et al. (2000b) inoculated E. coli $\mathrm{O} 157: \mathrm{H} 7$ on GBP and its population had a maximum reduction of $8.04 \log _{10} \mathrm{CFU}$ when gaseous chlorine dioxide was applied at, $0.60 \mathrm{mg} \mathrm{L}^{-1}$ concentrations at $20^{\circ} \mathrm{C}$ for $30 \mathrm{~min}$ with a relative humidity of $90-95 \%$. They concluded that gaseous chlorine dioxide concentration was an important factor in reducing the bacteria adhered to fresh produce surface. It is important to mention that subchronic effects (failure in thyroid metabolism by decrease of serum thyroxine) were observed in African Green monkeys when chlorine dioxide was administered in drinking water during 30-60 days, however these effects were observed after the fourth week of exposure at high dose of chlorine dioxide $(100 \mathrm{mg} / \mathrm{L})$; on the other hand, no toxic effects were observed in human volunteers who ingested $1 \mathrm{mg} / \mathrm{L}$ of chlorine dioxide in drinking water (Bercz et al., 1982), suggesting that the exposure to low dose do not show significant adverse effects. It is important to mention also that in this investigation, the exposure was in the GBP at low concentrations of 2 and $5 \mathrm{mg} / \mathrm{L}$ during 10 to 30 seconds, further reducing the possible adverse effects in humans. On the other hand, the phosphate buffered solution (control treatments) showed significant reductions. The highest reduction obtained with control treatment was $30 \mathrm{~s}$ at $\mathrm{pH} 6$ achieving a reduction of $3.11 \log _{10} \mathrm{CFU} / \mathrm{GBP}$, followed by treatment $30 \mathrm{~s}$ at $\mathrm{pH} 8$ which reduced $2.72 \log _{10} \mathrm{CFU} / \mathrm{GBP}$; however, there was no significant difference between both treatments $(p=1)$, which can be a "dragging effect" of spraying water. However, during "dragging" the bacteria is only detached from the surface, however, it does not mean a bactericidal effect that ensure bacterial elimination, which is necessary to ensure the absence of pathogenic bacteria in rinsing water, given it probable re-usage for packinghouse activities or releasing in the environment, becoming in a potential source of contamination. As shown by Pao et al. (2007) whom proved that washing with water can remove the microbial load from the fruits surface, but these are able to survive in water, becoming it a contamination route.

A few studies have been done on washing fruits and vegetables simulating the spraying process in agricultural packinghouses. In this study both disinfectants achieved higher bacterial reductions than those established by the scientific advisory group of US EPA, (1997) which states that, in order to consider the effectiveness of a disinfectant, it has to reduce at least $2 \log _{10} \mathrm{CFU}$ of the microorganism adhered to the surface of fruits and vegetables. In this study, reductions of $E$. coli $\mathrm{O} 157: \mathrm{H} 7$ were up to $7.74 \log _{10} \mathrm{CFU} / \mathrm{GBP}$ by chlorine dioxide at $5 \mathrm{mg} \mathrm{L}^{-1}$ and a contact time of $20 \mathrm{~s}$ regardless of $\mathrm{pH}$. These results suggest that chlorine dioxide can be considered as a viable alternative to chlorine in green bell peppers by using the spray-washing technique in agricultura packinghouses.

The differences in reduction of this study compared to the previously mentioned may be due to different inoculation methods, as well as initial microbial concentration, contact time, type of fruit, disinfection system, disinfectant forms, and enumeration method. More research is needed to assess aqueous chlorine dioxide simulating spray-washing technique of fruit and vegetables against various microorganisms such as Gram (+) bacteria, plant pathogens, protozoan of importance in public health, and enteric viruses.

\section{CONCLUSION}

Chlorine dioxide can be considered as a viable alternative to conventiona disinfection using Sodium hypochlorite in green bell peppers by the spraywashing technique in agricultural packinghouses. However, it is necessary to perform additional research focused on different vegetables and other public health-related pathogens, in order to validate the disinfection process using chlorine dioxide.

Acknowledgments: The authors thank MSc. Jorge Hernández, and MSc. Werner Rubio for their technical support.

\section{REFERENCES}

American Public Health Association/American Water Works Association/Water Environment Federation. (1998). Standard methods for the examination of water and wastewater. 20th Ed. Washington, DC.

American Public Health Association. (2001). Compendium of Methods for the Microbiological Examination of Foods. Fourth Edition, Washington DC. ISBN 10: 087553175X ISBN 13: 9780875531755.

Banach, J.L., Sampers, I., Haute, S.V. \& van der Fels-Klerx, H.I. (2015). Effect of Disinfectants on Preventing the Cross-Contamination of Pathogens in Fresh Produce Washing Water. Int. J. Environ. Res. Public Health. 12(8), 8658-8677. http://dx.doi.org/10.3390/ijerph120808658

Beuchat, L. (1996). Pathogenic microorganisms associated with fresh produce. $J$ Food Prot. 59(2), 204-216.

Beuchat L. (1998). Surface decontamination of fruits and vegetables eaten raw: a review. Food Safety Unit World Health Organization, (Report no. WHO/FS/FOS/98.2).

http://apps.who.int/iris/bitstream/10665/64435/1/WHO_FSF_FOS_98.2.pdf?ua= 1

Beuchat, L., Nail, B., Adler, B. \& Clavero, M. (1998). Efficacy of spray application of chlorinated water in killing pathogenic bacteria on raw apples, tomatoes, and lettuce. J. Food Prot. 61(10), 1305-1311.

Bercz, J.P., Jones, L., Garner, L., Murray, D., Ludwig, D.A., \& Boston, J. (1982) Subchronic toxicity of chlorine dioxide and related compounds in drinking water in the nonhuman primate. Environ. Health Perspect. 46, 47-55.

Centers for Disease Control and Prevention. (2002). Multistate outbreaks of Salmonella serotype Poona infections associated with eating cantaloupe from Mexico in United States and Canada, 2000-2002. Morb. Mort. Week. Rep. 51(46), 1044-1047.

Centers for Disease Control and Prevention. (2003). Hepatitis A Outbreak associated with green onions at a restaurant: Monaca, Pennsylvania, 2003. Morb. Mort. Week. Rep. 52(47), 1155-1157.

Centers for Disease Control and Prevention. (2005). Outbreaks of Salmonella infections associated with eating Roma tomatoes in United States and Canada, 2004. Morb. Mort. Week. Rep. 54(13), 325-328.

Centers for Disease Control and Prevention. (2006). Multistate Outbreak of Salmonella Typhimurium Infections Linked to Tomatoes (Final Update). http://www.cdc.gov/salmonella/typh2006/index.html.

Centers for Disease Control and Prevention. (2008). Outbreak of Salmonella serotype Saintpaul infections associated with multiple raw produce items in United States, 2008. Morb. Mort. Week. Rep. 57(34), 929-934.

Centers for Disease Control and Prevention. (2013). FDA Investigates Multistate Outbreak of Salmonella Saintpaul linked to cucumbers supplied by Daniel Cardenas Izabal and Miracle Greenhouse. http://www.fda.gov/Food/RecallsOutbreaksEmergencies/Outbreaks/ucm349461. htm

Centers for Disease Control and Prevention. (2016). Reports of Selected E. coli Outbreak Investigations. http://www.cdc.gov/ecoli/outbreaks.html.

Chaidez, C., López, J., Vidales, J., \& Castro-del Campo, N. (2007). Efficacy of chlorinated and ozonated water reducing Salmonella typhimurium attached to tomatoes surfaces. Int. J. Environ. Health Res., 2007. 17(4), 311-318. http://dx.doi.org/10.1080/09603120701417063

Cummings, K., Barrett, E., Mohle-Boetani, J. C., Brooks, J. T., Farrar, J., Hunt T., Fiore, A., Komatsu, K., Werner, S. B., \& Slutsker, L. (2001). A Multistate Outbreak of Salmonella enterica Serotype Baildon associated with domestic raw tomatoes. Emerg. Infect. Dis. 7(6), 1046-1048. https://wwwnc.cdc.gov/eid/article/7/6/01-0625_article

Du, J., Han, R., \& Linton, H. (2003). Efficacy of chlorine dioxide gas in reducing Escherichia coli O157:H7 on apple surfaces. Int. J. Food Microbiol. 20(5), $583-$ 591. https://doi.org/10.1016/S0740-0020(02)00129-6

Han, Y., Sherman, D., Linton, R., Nielsen, S. \& Nelson, P. (2000a). The effects of washing and chlorine dioxide gas on survival and attachment of Escherichia coli $\mathrm{O} 157: \mathrm{H} 7$ to green pepper surfaces. Int. J. Food Microbiol. 17(5), 521-533. http://doi.org/10.1006/fmic.2000.0343

Han, Y., Linton, R., Nielsen, S. \& Nelson, P. (2000b). Inactivation of Escherichia coli $\mathrm{O} 157: \mathrm{H} 7$ on surface-uninjured and -injured green pepper (Capsicum annum L.) by chlorine dioxide gas as demonstrated by confocal laser scanning microscopy. Int. J. Food Microbiol. 2000. 17(6), 643-655. https://doi.org/10.1006/fmic.2000.0357

Harwood, V.J., Staley, C., Badgley, B.D., Borges, K. \& Korajkic, A. (2014). Microbial source tracking markers for detection of fecal contamination in environmental waters: relationships between pathogens and human health outcomes. FEMS Mirobiol. Rev. 2014. 38(1), 1-40. https://doi.org/10.1111/1574$\underline{6976.12031}$

Hoffmann, S., Maculloch, B. \& Batz, M. (2015). Economic Burden of Major Foodborne Illnesses Acquired in the United States, EIB-140, U.S. Department of Agriculture, Economic Research http://www.ers.usda.gov/media/1837791/eib140.pdf.

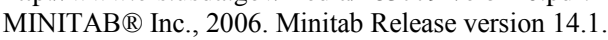


Pao, S., Kelsy, D., Khalid, F. \& Ettinger, M. (2007). Using aqueous chlorine dioxide to prevent contamination of tomatoes with Salmonella enterica and Erwinia carotovora during fruit washing. J. Food Prot. 70(3), 629-634.

Pao, S., Kelsey, D. \& Long III, W. (2009). Spray washing of tomatoes with chlorine dioxide to minimize Salmonella on inoculated fruit surfaces and crosscontamination from revolving brushes. J. Food Prot. 72(12), 2488-2452.

Ravaliya, K., Gentry-Shieldsa, J., Garcia, S., Heredia, N., Fabiszewski de Aceituno, A., Bartz, F.E., Leon, J.S. \& Jaykus, L.A. (2014). Use of Bacteroidales Microbial Source Tracking to Monitor Fecal Contamination in Fresh Produce Production. Appl. Environ. Microbiol. 2014. 80(2), 612-617. http://dx.doi.org/10.1128/AEM.02891-13

Rudd, T., \& Hopkinson, L. (1989). Comparison of disinfection techniques for sewage and sewage effluents. Water Environ. J. 3(6), 612-618. http://dx.doi.org/10.1111/j.1747-6593.1989.tb01443.x

Scallan, E., Hoekstra, R.M., Angulo, F.J., Tauxe, R.V., Widdowson, M-A., Roy, S.L., Jones, J.L., \& Griffin, P.M. (2011). Foodborne illness acquired in the United States of America-Major pathogens. Emerging Infectious Diseases. 17(1), 7-15. http://wwwnc.cdc.gov/eid/article/17/1/pdfs/p1-1101.pdf.

Singh, N., Singh, R.K., Bhunia, A.K. \& Stroshine, L. (2002). Efficacy of chlorine dioxide, ozone, and thyme essential oil or a sequential washing in killing Escherichia coli O157:H7 on Lettuce and Baby Carrots. Lebensmittel$\begin{array}{llll}\text { Wissenschaft } & \text { und-Technologie. } & \text { 35(8), }\end{array}$ https://doi.org/10.1006/fstl.2002.0933

[US EPA] United States Environmental Protection Agency. (1997). FIFRA Scientific Advisory Panel "A set of scientific issues being considered by the Agency in connection with the exposure assessment methodologies for residential scenarios".

http://www.epa.gov/scipoly/sap/meetings/1997/september/finalsep.htm\#3.

[U.S. FDA] Food and Drug Administration, Code of Federal Regulations Title http://www.accessdata.fda.gov/SCRIPTs/cdrh/cfdocs/cfcfr/CFRSearch.cfm. Wang, G., Clark, C.G. \& Rodgers, F.G. (2002). Detection in Escherichia coli of the Genes Encoding the Major Virulence Factors, the Genes Defining the O157:H7 Serotype, and Components of the Type 2 Shiga Toxin Family by Multiplex PCR. J. Clin. Microbiol. 2002. 40(10), 3613-3619. https://dx.doi.org/10.1128/JCM.40.10.3613-3619.2002 